\title{
The effect of corporate ownership on inventory management by considering corporate governance as a mediator
}

\author{
Hossein Mehrabani ${ }^{\mathbf{a}^{*}}$ and Hossein Izadi $^{\mathbf{b}}$
}

\begin{abstract}
${ }^{a}$ PhD student in Accounting and CPA, Department of Management and Accounting, Qom Branch, Islamic Azad University, Qom, Iran ${ }^{b}$ Assistant Professor, Department of Management and Accounting, Islamic Azad University, Islam Shahr Branch, Tehran, Iran

C H R O N I C L E

\begin{tabular}{l}
\hline Article history: \\
Received March 25, 2015 \\
Received in revised format 28 \\
March 2015 \\
Accepted 20 May 2015 \\
Available online \\
May 252015 \\
\hline Keywords: \\
Tehran Stock Exchange \\
Corporate governance \\
Corporate Ownership \\
Inventory Management \\
\hline
\end{tabular}
A B S T R A C T

In this study, we examine the relationship between corporate ownership and inventory management where corporate governance plays as a mediator. The study selects a sample of 166 selected firms listed on Tehran Stock Exchange using historical data over the period 20092013. The study considers the role of managers as shareholder, existence of managers with more than one responsibility and size of board of directors on inventory management. Using regression analysis, the study has disclosed a negative relationship between managers as shareholder and board size on one side and inventory size on the other side. However, the study did not find any evidence on relationship between managers' dual responsibility as a mediator on relationship between corporate ownership and in inventory management.
\end{abstract}

C 2015 Growing Science Ltd. All rights reserved.

\section{Introduction}

Inventory is one of the most important components of current assets in any business units and management of inventory may increase profitability, significantly (Christie \& Zimmerman, 1994; Krautter, 1999; Tribó, 2007). Chekili (2012) investigated the effect of some governance mechanisms on earnings management listed on Tunisian firms over the 2000-2009 by considering 200 observations. In this survey, earnings management was operationalized as a function of board of directors' size, presence of external directors within the board, the separation between the manager and president of the board roles, the majority shareholder's capital percentage, managers' shareholdings, presence of financial institutions and appointment of the CEO by the state. They reported that presence of external directors within the board, board size and presence of a CEO appeared to influence on earnings management whereas the other board characteristics were detected to be neutral. Basu and Wang (2011) confirmed a negative relationship between inventory changes and firm performance but reported that the relationship was sensitive to the choice of sample period. In addition, the relationship was somewhat attenuated for companies in the wholesale and retail industry as well as for firms that normally carry low levels of inventory. They indicated that the macroeconomic and industry-specific environments were important moderators of the relationship between inventory changes and firm performance.

\footnotetext{
* Corresponding author.

E-mail address: info@taxaccounting.ir (H. Mehrabani) 
Mansor et al. (2013) provided some support on the idea that corporate governance (CG) mechanisms were capable of overcoming earnings management (EM) activities specifically from the perspective of family owned companies (FOC) and the non-family owned companies (NFOC). They reported that for FOC, only number of board meetings held; while for NFOC, independence of directors, audit committee, non-duality, audit committee size, in-house internal audit function and quality differentiated auditors were the CG mechanisms detected to be able to help in minimizing the EM activities. Maher and Andersson (2000) studied some of the strengths, weaknesses, and economic implications related to different corporate governance systems in OECD countries. They discussed different mechanisms employed in various systems (e.g. the market for corporate control, executive remuneration schemes, concentrated ownership, cross-shareholdings amongst firms) and evaluated the evidence on whether or not they were conducive to company performance and economic growth. For instance, they explained how the corporate governance framework could impinge on the development of equity markets, R\&D and innovative activity, and the development of an active SME sector, and thus impinge on economic growth.

Elsayed and Wahba (2013) tried to learn whether or not the relationship between institutional ownership and inventory management could be moderated by other internal corporate governance mechanisms. Econometric analysis, using a sample of Egyptian listed firms, in their survey provided strong evidence for the applicability of this theme and demonstrates that institutional ownership could influence on inventory management positively (negatively) when managerial ownership was high (low), CEO duality (non-duality) was in place, or board size was large (small). Ameer (2010) investigated the role of institutional investors in the inventory and cash management practices of firms in Asia. They examined the role of a particular class of institutional investors, domestic and foreign banks, in corporate decisions that have liquidity implications such as inventory and cash management. They reported that foreign banks could improve inventory and cash management practices, due to their superior monitoring of the managers. The disproportionate numbers of the institutional investors across industrial sectors in these Asian countries appeared to recommend that some industrial sectors had stable demand of their products, such as in consumer goods sector, which is an attraction, for these institutional investors. Moreover, they reported that forward-looking government policies were crucial to entry of these institutional investors in the developing countries.

Ben-Nasr et al. (2012) applied a unique dataset of 233 privatized companies from 38 countries over the period 1985-2008 to find out the relationship between shareholder identity and earnings quality. They reported strong and robust evidence that (residual) state ownership was related to lower earnings quality. In addition, they reported that state ownership was related to higher abnormal accruals and that the adverse impacts of state ownership on earnings quality were less pronounced in countries with strong investor protection. Moreover, they reported some evidence recommending that private ownership could help to mitigate the adverse impacts of state ownership. Finally, they reported that government-controlled firms with lower earnings quality were penalized with a higher cost of equity.

\section{The proposed study}

In this study, we examine the relationship between corporate ownership and inventory management where corporate governance plays as a mediator. The study selects a sample of 166 selected firms listed on Tehran Stock Exchange using historical data over the period 2009-2013, which yields 830 panel data. The study considers the effects the role of managers as shareholder, existence of managers with more than one responsibility and size of board of directors on inventory management. The study considers the following three hypotheses,

1. There is a meaningful positive/negative relationship between corporate ownership and inventory management when managers’ corporate ownership increases. 
2. There is a meaningful positive/negative relationship between corporate ownership and inventory management when board of directors maintain more than one responsibility.

3. There is a meaningful positive/negative relationship between corporate ownership and inventory management when size of board of directors increases/decreases.

The following summarizes descriptions of the variables used for the proposed study of this paper.

\section{Dependent variable}

IVS: Inventory value to sales, which is measured as a ratio of total inventory on sales of items.

\section{Independent variable}

INS: corporate ownership, which is measured as a ratio of totals shares own by institutional firms divided by total outstanding shares.

\section{Control variables}

$B O A$ : This is a dummy variable representing the size of the firm, which is one if firm has more than 6 members as board of director and zero, otherwise.

MAN: This variables measure the ratio of management ownership, which is calculated by dividing sum of top management ownership by total outstanding shares.

$B L S$ : This is a dummy variable representing dual responsibility in management and it receives a value one if chief director is also responsible as executive manager and zero, otherwise.

GRO: This variables measures the growth of the firm using Tobin-Q.

Size: This variable determines how big is the size of the firms are.

PRO: This variable measures the profitability of the firms and it is measured based reported earnings before tax.

$L E V$ : This variable is associated with leverage and it is measured as the ratio of total liabilities on total assets.

CAP: This variable measures the amount of investment, which is calculated as the ratio of total equipment on total liabilities.

AGE: This variable measures the age of firms participated in this survey.

SEC: This variable measures the effects of industry using two digit ISIC classification.

$P R V$ : This variable is one when the firm is mostly owned by private sector and zero, otherwise.

HOL: This variable is one when the firm is mostly owned by government and zero, otherwise.

INT: This variable is one when the firm is mostly owned by institutions and zero, otherwise.

The proposed study of this paper uses a two-stage regression technique to examine the hypotheses of the survey. We first estimate the following function

$$
\begin{aligned}
& I V S_{\mathrm{it}}=\alpha_{0}+\alpha_{1} I N S_{\mathrm{it}}+\alpha_{2} M A N_{\mathrm{it}}+\alpha_{3} B L S_{\mathrm{it}}+\alpha_{4} B O A_{\mathrm{it}}+\alpha_{5} G R O_{\mathrm{it}}+\alpha_{6} \operatorname{Size}_{\mathrm{it}}+\alpha_{7} P R O_{\mathrm{it}}+\alpha_{8} L E V_{\mathrm{it}}+\alpha_{9} \\
& C A P_{\mathrm{it}}+\alpha_{10} A G E_{\mathrm{it}}+\alpha_{11} P R V_{\mathrm{it}}+\alpha_{12} H O L_{\mathrm{it}}+\alpha_{13} S E C_{\mathrm{it}}+\varepsilon_{\mathrm{it}},
\end{aligned}
$$

and for the second stage, the study uses the following regression function, 


$$
\begin{aligned}
& I V S_{\mathrm{it}}=\alpha_{0}+\alpha_{1} I N S_{\mathrm{it}}+\alpha_{2} M_{\mathrm{it}}+\alpha_{3} I N S_{\mathrm{it}} \times M A N_{\mathrm{it}}+\alpha_{4} B L S_{\mathrm{it}}+\alpha_{5} I N S_{\mathrm{it}} \times B L S_{\mathrm{it}}+\alpha_{6} \mathrm{i}_{\mathrm{it}}+\alpha_{7} \mathrm{INS}_{\mathrm{it}} \times \mathrm{BOA}_{\mathrm{it}}+ \\
& \alpha_{8} G R O_{\mathrm{it}}+\alpha_{9} \text { Size }_{\mathrm{it}}+\alpha_{10} P R O_{\mathrm{it}}+\alpha_{11} L E V_{\mathrm{it}}+\alpha_{12} C A P_{\mathrm{it}}+\alpha_{13} A G E_{\mathrm{it}}+\alpha_{14} P R V_{\mathrm{it}}+\alpha_{15} H O L_{\mathrm{it}}+\alpha_{17} S E C_{\mathrm{it}}+\varepsilon_{\mathrm{it}} .
\end{aligned}
$$

where $I N S_{i t} \times M A N_{i}, I N S_{i t} \times B L S_{i t}$ and $\mathrm{INS}_{\mathrm{it}} \times \mathrm{BOA}_{\mathrm{it}}$ are used to examine the first, second and third hypotheses, respectively. In addition, $\alpha_{3}, \alpha_{5}$ and $\alpha_{7}$ represent the signs of the three relationships, respectively. Table 1 shows the results of some basic statistics associated with the proposed study.

\section{Table 1}

The summary of some basic statistics

\begin{tabular}{lccccccc}
\hline Variable & Symbol & Mean & Median & Max & Min & Standard deviation & Kurtosis \\
\hline Inventory efficiency & IVS & 1.915 & 0.465 & 199.941 & 0 & 9.839 & 5.35 \\
Corporate ownership & INS & 49.724 & 50.54 & 99.145 & 0 & 23.978 & -0.124 \\
Profitability & PRO & 0.087 & 0.088 & 0.676 & -0.89 & 0.168 & -0.894 \\
Corporate governance & MAN & 23.745 & 21.1 & 94.93 & 0 & 18.415 & 0.648 \\
Leverage & LEV & 1.227 & 0.726 & 58.989 & 0.041 & 3.172 & 1.883 \\
Private ownership & PRV & 71.722 & 77.23 & 100 & 0 & 25.239 & -1.485 \\
Firm size & SIZE & 5.579 & 5.583 & 8.056 & 3.368 & 0.78 & 0.106 \\
Government ownership & HOL & 17.002 & 8.67 & 89.93 & 0 & 21.754 & 1.752 \\
Growth & GRO & 5.356 & 2.595 & 151.613 & 0 & 8.964 & 6.162 \\
Capital sensitivity & CAP & 0.194 & 0.136 & 0.891 & 0 & 0.188 & 1.241 \\
Size of board of directors & BOA & 0.193 & 0 & 1 & 0 & 0.022 & -0.832 \\
Management ownership & BLS & 0.565 & 1 & 1 & 0 & 0.496 & -0.263 \\
Firm age & AGE & 14.106 & 15 & 22 & 4 & 4.551 & -0.481 \\
\hline
\end{tabular}

The results of Table 1 have indicated that the ownership for some firms is well above $50 \%$ and there are some data, which are outside the limits. We have decided to remove some out region data to prepare a more suitable data. Table 2 shows the summary of correlation among various variables and the results do not indicate a strong correlation among independent variables. Moreover, Table 3 presents the results of Kolmogorov-Smirnov test.

Table 2

\begin{tabular}{|c|c|c|c|c|c|c|c|c|c|c|c|c|c|}
\hline Var. & PRV & PRO & MAN & LEV & IVS & INS & HOL & GRO & CAP & BOA & BLS & AGE & SIZE \\
\hline PRV & 1 & & & & & & & & & & & & \\
\hline PRO & 0.02 & 1 & & & & & & & & & & & \\
\hline MAN & 0.002 & -0.006 & 1 & & & & & & & & & & \\
\hline LEV & -0.23 & -0.003 & -0.01 & 1 & & & & & & & & & \\
\hline IVS & -0.07 & -0.023 & 0.193 & 0.039 & 1 & & & & & & & & \\
\hline INS & 0.046 & -0.247 & 0.004 & -0.023 & -0.008 & 1 & & & & & & & \\
\hline HOL & -0.01 & -0.023 & 0.013 & -0.13 & -0.143 & 0.018 & 1 & & & & & & \\
\hline GRO & 0.251 & 0.037 & -0.01 & -0.28 & -0.018 & 0.002 & 0.009 & 1 & & & & & \\
\hline CAP & 0.015 & -0.017 & -0.01 & -0.008 & -0.03 & 0.027 & -0.062 & 0.021 & 1 & & & & \\
\hline BOA & -0.04 & 0.017 & -0.04 & 0.045 & -0.055 & 0.005 & 0.048 & -0.03 & 0.014 & 1 & & & \\
\hline BLS & -0.08 & -0.022 & -0.02 & 0.0416 & 0.048 & 0.007 & -0.119 & -0.15 & -0.024 & -0.001 & 1 & & \\
\hline AGE & 0.021 & 0.012 & 0.048 & -0.046 & -0.283 & 0.007 & 0.175 & -0.05 & -0.025 & -0.08 & -0.05 & 1 & \\
\hline SIZE & -0.08 & -0.005 & -0.27 & 0.018 & 0.0506 & -0.01 & -0.101 & 0.002 & -0.02 & -0.043 & 0.024 & -0.15 & 1 \\
\hline
\end{tabular}

The summary of the correlations among different pairs of data

\section{Table 3}

The summary of Kolmogorov-Smirnov test

\begin{tabular}{lccccc}
\hline Variable & IVS & INS & BOA & BLS & MAN \\
\hline Sig. & 0.029 & 0.592 & 0.089 & 0.175 & 0.12 \\
Result & Not normal & Normal & Normal & Normal & Normal \\
\hline
\end{tabular}

According to the results of Table 3, only IVS is not normally distributed and the other variables are normally distributed. Therefore, Johnson test to convert the data into normal for this variable. Table 4 presents the results of Limer and Hausman. According to the results of Table 4 we use panel data with fixed effect. 
Table 4

The summary of Limer and Hausman test

\begin{tabular}{lccccc}
\hline & Limer & \multicolumn{4}{c}{ Hausman } \\
\hline F-value & df & Sig. & Chi-Square & df & Sig. \\
\hline 22.43 & 165 & 0.0087 & 5.635 & 15 & 0.8966 \\
\hline
\end{tabular}

\section{The results}

In this section, we present details of our findings on testing the hypotheses of this survey using regression method. We first examine the effects of independent variables on dependent variable before taking into account the effects of control variables and Table 5 shows the results.

\section{Table 5}

The summary of regression analysis before taking into account the effects of control variables

\begin{tabular}{|c|c|c|c|c|}
\hline Variable & Symbol & coefficient & t-value & Sig. \\
\hline Corporate ownership & INS & -0.04797 & -2.4157 & 0.020649 \\
\hline Corporate management & MAN & -0.11944 & -2.53984 & 0.022352 \\
\hline Dual responsibility & BLS & 0.642209 & 4.07451 & 0.050877 \\
\hline Board size & BOA & -0.02839 & -2.93312 & 0.008408 \\
\hline Growth & GRO & 0.032306 & 1.09635 & 0.338468 \\
\hline Firm size & SIZE & 0 & 4.639163 & 0.000 \\
\hline Profitability & PRO & -9.29147 & -5.51031 & 0.000 \\
\hline Leverage & LEV & -0.02545 & -0.32187 & 0.819561 \\
\hline Capital sensitivity & CAP & -1.19239 & -0.90081 & 0.439583 \\
\hline Firm age & AGE & 0.059718 & 1.062295 & 0.355498 \\
\hline Private ownership & PRV & 0.045033 & 1.420421 & 0.208616 \\
\hline Government ownership & HOL & -0.00294 & -0.21532 & 0.899389 \\
\hline Intercept & C & 1.532098 & 0.652537 & 0.588594 \\
\hline R-squared & & 0.815487 & Mean & 1.895 \\
\hline Adjusted R-squared & & 0.789 & Durbin-Watson & 2.125 \\
\hline F-statistic & & 4.229 & Sig, & 0.000 \\
\hline
\end{tabular}

According to the results of Table three variables, INS, MAN and BOA maintain meaningful relationships with dependent variable but BLS does not have any meaningful relationship. Table 6 presents the results by considering the control variables.

\section{Table 6}

The summary of regression analysis before taking into account the effects of control variables

\begin{tabular}{lcccc}
\hline \multicolumn{1}{c}{ Variable } & Symbol & Coefficient & t-value & Sig. \\
\hline Corporate ownership & INS & -0.049 & -2.199 & 0.0194 \\
Corporate management & MAN & -0.122 & -2.312 & 0.021 \\
& MAN×INS & 0.002 & 2.374 & 0.018 \\
Dual responsibility & BLS & 0.656 & 3.709 & 0.0478 \\
Board size & INS $\times$ BLS & 0.014 & 0.451 & 0.0652 \\
& BOA & -0.029 & -2.67 & 0.0079 \\
Growth & INS ×BOA & 0.003 & 5.855 & 0.0393 \\
Firm size & GRO & 0.033 & 0.998 & 0.318 \\
Profitability & SIZE & 0 & 4.223 & 0.000 \\
Leverage & PRO & -9.491 & -5.016 & 0.000 \\
Capital sensitivity & LEV & -0.026 & -0.293 & 0.77 \\
Firm age & CAP & -1.218 & -0.82 & 0.413 \\
Private ownership & AGE & 0.061 & 0.967 & 0.334 \\
Government ownership & PRV & 0.046 & 1.293 & 0.196 \\
Intercept & HOL & -0.003 & -0.196 & 0.845 \\
\hline R-squared & C & 1.565 & 0.594 & 0.553 \\
Adjusted R-squared & & 0.833 & Mean & \\
F-statistic & & 0.816 & Durbin-Watson & 2.02 \\
& & 3.358 & Sig, & 0.000
\end{tabular}

According to Table 6, Adjusted R-Square is equal to 0.816, which means that the independent variables could describe approximately $82 \%$ of the changes of dependent variable. In addition, Durbin-Watson 
is equal to 2.02, which means there was no auto-correlation among independent variables. Moreover F-value is statistically meaningful, which means the relationships are linear.

\section{Discussion and conclusion}

As we can observe from the results of Table 6, there is a negative and meaningful relationship between corporate ownership (INS) and inventory management. In addition, the sign of MAN $\times$ INS is also positive, which means the relationship is positive.

The second hypothesis of the survey studies the effects of dual responsibility (BLS) on inventory management and as we can observe the coefficient is not meaningful when the level of significance is one percent. Therefore, the second hypothesis of the survey has not been approved.

Finally, the last hypothesis of the survey investigates the relationship between board size (BOA) and inventory management. As we can observe from the results of the survey, there is a negative and meaningful relationship between these two variables.

The results of this study are consistent with findings of Elsayed and Wahba (2013) and Ben-Nasr et al. (2012).

\section{Acknowledgement}

The authors would like to thank the anonymous referees for constructive comments on earlier version of this paper.

\section{References}

Ameer, R. (2010). The role of institutional investors in the inventory and cash management practices of firms in Asia. Journal of Multinational Financial Management, 20(2), 126-143.

Basu, N., \& Wang, X. (2011). Evidence on the relation between inventory changes, earnings and firm value. The International Journal of Business and Finance Research, 5(3), 1-14.

Ben-Nasr, H., Boubakri, N., \& Cosset, J. C. (2012). Earnings quality in privatized firms: International evidence on the role of state and private owners. Available at SSRN 2161478.

Chekili, S. (2012). Impact of some governance mechanisms on earnings management: An empirical validation within the Tunisian market. Journal of Business Studies Quarterly, 3(3), 95-104.

Christie, A. A., \& Zimmerman, J. L. (1994). Efficient and opportunistic choices of accounting procedures: Corporate control contests. Accounting Review, 69(4), 539-566.

Elsayed, K., \& Wahba, H. (2013). Reinvestigating the relationship between ownership structure and inventory management: A corporate governance perspective. International Journal of Production Economics, 143(1), 207-218.

Krautter, J. (1999). Inventory theory: New perspectives for corporate management. International Journal of Production Economics, 59(1), 129-134.

Maher, M., \& Andersson, T. (2000). Corporate governance: effects on firm performance and economic growth. Available at SSRN 218490.

Mansor, N., Che-Ahmad, A., Ahmad-Zaluki, N. A., \& Osman, A. H. (2013). Corporate governance and earnings management: A study on the Malaysian family and non-family owned PLCs. Procedia Economics and Finance, 7, 221-229.

Tribó, J. A. (2007). Ownership structure and inventory policy. International Journal of Production Economics, 108(1), 213-220. 